\title{
Expression of a Defense-Related 3-Hydroxy-3- Methylglutaryl CoA Reductase Gene in Response to Parasitization by Orobanche spp.
}

\author{
James H. Westwood, Xueshu Yu, Chester L. Foy, and Carole L. Cramer \\ Department of Plant Pathology, Physiology and Weed Science, Virginia Polytechnic Institute and State \\ University, Blacksburg, VA 24061-0331, U.S.A. \\ Accepted 7 February 1998.
}

\begin{abstract}
Orobanche spp. are angiosperms that live parasitically on the roots of other plants, and are capable of significantly reducing the yield and quality of their crop hosts. We have demonstrated that parasitization by Orobanche induces expression of hmg2, a defense-related isogene of 3hydroxy-3-methylglutaryl CoA reductase (HMGR) in tobacco. Transgenic tobacco plants expressing a construct containing $2.3 \mathrm{~kb}$ of the tomato $\mathrm{hmg} 2$ gene promoter fused to the $\beta$-glucuronidase (GUS) reporter gene were parasitized by $O$. aegyptiaca. Expression of the hmg2:GUS construct was detected within 1 day following penetration of the host root by the $O$. aegyptiaca radicle and was localized to the region immediately around the site of parasite invasion. This expression continued and intensified over the course of $O$. aegyptiaca development. In addition, the hmg2:GUS expression was induced by secondary parasitization, where secondary roots of $O$. aegyptiaca contacted the host root at a distance from the primary attachment site. This GUS expression was specific to plants containing the hmg2:GUS construct, and was not observed in control plants transformed with a construct of the cauliflower mosaic virus $35 \mathrm{~S}$ promoter fused to the GUS gene. These results indicate that Orobanche parasitization initiates rapid and sustained induction of a defense-related gene in the host root.
\end{abstract}

Additional keywords: broomrape, Nicotiana tabacum, parasitic weed.

Orobanche spp. (broomrapes) are parasitic angiosperms that subsist on the roots of a variety of dicotyledonous plants. Orobanche spp. vary in their specificity for hosts, but important crops attacked include members of the Solanaceae, Fabaceae, Compositae, Cruciferae, and Umbelliferae families (Parker and Riches 1993). Orobanche are among the most destructive weeds because they extract water and photosynthates directly from crop plants, causing significant reductions in crop yield and quality (Sauerborn 1991). Their greatest economic impact is in semiarid regions of the world, especially

Corresponding author: James H. Westwood; Telephone: 540-231-7519; Fax: 540-231-7477; E-mail: westwood@vt.edu

Current address of X. Yu: Department of Biochemistry and Microbiology, University of Victoria, BC Canada. the Mediterranean and Middle East, where Orobanche are endemic. These parasitic weeds are difficult to control because they are closely associated with the host root and are concealed underground for most of their life cycle. Thus, mechanical control is impossible until after the floral shoot has emerged, by which time the parasite has already caused significant damage to the host. Applying herbicide to the subterranean parasite is also difficult, and is further complicated by the lack of herbicidal selectivity between host and Orobanche (Foy et al. 1989). The most effective chemical control method has been fumigation of soil to kill seeds, but this is costly and hazardous to the environment. Recently, herbicide-resistant crops have been shown to offer an excellent opportunity for controlling Orobanche spp. because they allow a translocatable herbicide to move though the host to the parasite (Joel et al. 1995), but this is dependent on the creation of herbicideresistant crop varieties and may be countered by the development of resistant populations of Orobanche (Gressel et al. 1996). The best long-term strategy for limiting damage by Orobanche is the development of Orobanche-resistant crops, but traditional plant breeding has generally failed to produce resistance that is durable across time or variations of location and parasite pressure (Cubero 1991). Characterization of parasite-resistant crops suggests that the parasite life cycle may be interrupted at any of several critical points (described below), although the fundamental biology of these resistance mechanisms is still unclear (Lane et al. 1993; Wegmann et al. 1991; Vogler et al. 1996).

The parasitic life-style requires a close association with a host plant, and Orobanche has evolved complex mechanisms of communication and physiological interaction with its hosts (reviews of the biology and physiology of Orobanche and a similar parasite, Striga, may be found in Parker and Riches 1993; Press et al. 1990; Stewart and Press 1990). The initial interaction between parasite and host is the requirement by Orobanche seed for a specific chemical germination signal, normally exuded by roots of a compatible host plant. The parasite radicle then emerges and must contact, penetrate, and form vascular connections (via a haustorium) with the root of a host plant before further development can occur.

In Orobanche, the radicle adheres to the host root by the secretion of a carbohydrate substance (Joel and Losner-Goshen 1994a) and then penetrates the root with the aid of enzymes capable of digesting pectins, cellulose, and other carbohy- 
drates (Ben-Hod et al. 1993; Shomer-Ilan 1993). The parasite appears to grow between, rather than through, host cortex cells (Joel and Losner-Goshen 1994a) and forms a haustorium that connects the parasite to the host xylem and phloem tissues. At this time, the cells of the Orobanche haustorium are intimately associated with host cells, and Orobanche sieve elements share plasmodesmatal connections with sieve elements of the host phloem (Dörr 1996).

Once vascular connections have been established, Orobanche draws its water and nutrition from the host. The Orobanche radicle adjacent to the host root surface swells and develops into a bulbous mass of tissue called a tubercle, from which arise stunted, unbranching roots. The role of these secondary roots has not been well studied in Orobanche, though there is evidence that they are capable of functioning in water and phosphorous uptake (Ismail and Obeid 1976). In Striga and certain Orobanche spp., these roots readily form secondary attachments to neighboring host roots (Kuijt 1977; Visser and Dörr 1987). Ultimately, the tubercle initiates a floral meristem that develops into a floral spike that is the parasite's only aboveground structure.

Plants contain genes whose expression is triggered in response to pathogen ingress. These genes may encode proteins that are involved in a variety of plant defenses, such as synthesis of phytoalexins, evolution of reactive oxygen species, production of pathogenesis-related (PR) proteins, reinforcement, of cell walls, or regulation of the hypersensitive response (Lamb et al. 1989; Hammond-Kosack and Jones 1996). Although plant expression of these genes may not always lead to pathogen resistance, they are commonly referred to as "defense-related" genes based on their induction following pathogen invasion or wounding (Lamb et al. 1989; Cramer et al. 1993). The process of signaling in defense responses is not completely understood, but varies with the mode of pathogenesis of the invading organism such that specific pathogens induce characteristic patterns of defenserelated gene expression.

Investigation of the molecular regulation of the host defense response to parasitic weed attack will increase our understanding of the interaction between host and parasite, and provide tools necessary for engineering novel resistance mechanisms into crop species for which no Orobanche-resistant cultivars are available. In studies on the molecular basis of host-pathogen interactions, a tomato (Lycopersicon esculentum Mill.) gene, hmg2, has been identified that is activated in response to a variety of biotic and abiotic stresses (Park et al. 1992). This gene is one of four differentially regulated $\mathrm{hmg}$ genes in tomato that encode 3-hydroxy-3-methylglutaryl CoA reductase (HMGR), considered the rate limiting enzyme in the isoprenoid biosynthetic pathway (Chappell 1995). hmg2 is specifically activated during defense responses associated with the production of sesquiterpene phytoalexins (Cramer et al. 1993; Chappell 1995). Transgenic tobacco expressing fusions of the $h m g 2$ promoter to the $\beta$-glucuronidase (GUS) reporter gene have been used to assess the temporal and spatial regulation of $h m g 2$ during host-pathogen interactions. Expression of $h m g 2$ is high in cells at the site of pathogen ingress or cells surrounding lesions caused by tobacco mosaic virus, Rhizoctonia solani, the soft rot bacterium Erwinia carotovora subsp. carotovora, and the parasitic root knot nematode Meloidogyne incognita (Cramer et al. 1993; X. Yu, D. L.
Weissenborn, G. H. Lacy, S. A. Tolin, and C. L. Cramer, unpublished results). Wounding by excision, insect predation, and elicitor treatment also triggered induction of the hmg2:GUS construct. Because $h m g 2$ is activated by such a diversity of pathogens in both compatible and incompatible interaction, it serves as an interesting and promising candidate to test for response to Orobanche parasitization.

Our long-range objectives are to understand the molecular interactions that occur during Orobanche parasitization and to develop and test strategies for genetically enhancing host resistance to Orobanche. This paper characterizes the expression of a host defense-response gene, tomato $h m g 2$, during parasitization by $O$. aegyptiaca Pers. We initially noted that $h m g 2$ expression was induced in response to $O$. aegyptiaca parasitization (Westwood et al. 1996). The current research demonstrates specific temporal and spatial regulation of hmg2 gene expression initiated early in the penetration phase and maintained at sites of contact throughout $O$. aegyptiaca development.

\section{RESULTS}

The ability of Orobanche parasitization to induce host expression of hmg2 was evaluated with tobacco (Nicotiana tabacum) plants containing gene promoter:reporter fusions. Plants contained either $2.3 \mathrm{~kb}$ of the tomato hmg2 promoter or the cauliflower mosaic virus (CaMV) $35 \mathrm{~S}$ promoter fused to the GUS reporter gene. Tobacco roots were exposed to germinating seeds of $O$. aegyptiaca and GUS expression detected by histochemical staining at various times following initial contact of the host roots by the parasite radicle. The GUS gene product, $\beta$-glucuronidase, enzymatically converts the colorless substrate 5-bromo-4-chloro-3-indolyl- $\beta$-D glucuronide into a bright blue pigment that is easily identified in plant root tissues.

Plants transformed with the constitutively expressed CaMV $35 \mathrm{~S}$ promoter fused to the GUS gene were used for comparison because $35 \mathrm{~S}$ expression is not known to be wound or defense related (in roots of our transformants the $35 \mathrm{~S}$ promoter was highly active only in meristems) (Fig. 1A, B, and C). Figure 1A shows an $O$. aegyptiaca seedling in the process of penetrating the host root, while attachment is complete in the plants shown in Figures 1B and C. In none of these cases did the host root exhibit GUS expression, indicating 35S promoter activity in response to parasitization by Orobanche.

Orobanche penetration specifically induced GUS expression in roots of tobacco plants containing the hmg2:GUS construct. The $h m g 2$ promoter was induced only after penetration of the host root by Orobanche; parasite seedlings that merely adhered to the root surface did not induce blue color in the host root (Fig. 1D). Orobanche plants that had penetrated the host tissue (1 day after contact) induced the expression of GUS specifically in the region of penetration, as indicated by the development of blue pigment at the point of union between the organisms (Fig. 1E and F). This expression was visible in cortex tissue as well as in the vascular tissue. The intensity of GUS expression increased with parasite development, as shown in Figure 1G, H, and I, where 1I represents a tubercle approximately 10 days old. In all cases, expression of $h m g 2$ was localized around the region of parasite attachment and was not observed in unparasitized regions of the roots, 
except for the developmentally controlled $h m g 2$ expression at sites of lateral root emergence (Weissenborn et al. 1995). Although blue color was occasionally observed in tubercles at the point of attachment (i.e., Fig. 1I), this was due to diffusion of the pigment from root to tubercle during staining. Tubercles excised from roots prior to staining showed no GUS expression (data not shown), nor was blue ever observed in Orobanche tissues that had not parasitized $h m g 2$ :GUS-containing plants.

The expression of hmg2:GUS was also visible during advanced stages of Orobanche development, and was therefore not solely the result of a transient expression induced by the initial penetration event. Rather, a sustained level of intense GUS expression in the area of Orobanche attachment continued throughout the development of tubercles through 4 weeks of growth in the laboratory (Fig. 2). Again, no blue pigment was observed in parasitized plants containing 35S:GUS constructs (Fig. 2A), indicating that GUS expression was specific to the $h m g 2$ promoter (Fig. 2B). Furthermore, the secondary roots of Orobanche also induced hmg2:GUS expression at points of contact with the host roots (Fig. 2C and D).

Analogous $h m g 2$ :GUS expression patterns were seen in $N$. tabacum cvs. Xanthi (shown) and NC 95 (data not shown), which represent two independently transformed lines. A second Orobanche species, O. ramosa L., induced GUS expression patterns identical to those of $O$. aegyptiaca (data not shown).

\section{DISCUSSION}

The penetration of the host root by Orobanche and the establishment of stable cell to cell connections between host and parasite constitute a very unique and complex interaction. Neither the molecular processes nor the chemical signals that mediate this interaction are well understood. Study of gene regulation in a host plant during this process can reveal much


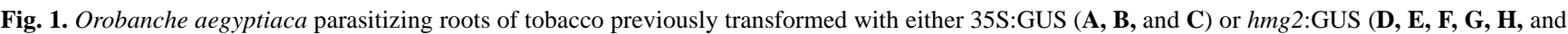
I) gene constructs. $O$. aegyptiaca seedlings within 1 day of root contact $(\mathbf{A}, \mathbf{E}$, and $\mathbf{F}$ ) show the parasite radicle (r) penetrating the host root (hr), and GUS expression only in roots with the hmg2:GUS construct. No GUS expression is evident where O. aegyptiaca attachment has occurred without host root penetration (D). As the tubercle (t) forms adjacent to the host root and the remainder of the seed (s) (B and $\mathbf{G})$, and during subsequent tubercle development $(\mathbf{C}$ and $\mathbf{H})$, intense GUS expression continues in $h m g 2$ :GUS plants in the area of attachment. This expression is sustained in roots adjacent to tubercles approximately 10 days after initial contact with the parasite (I). Bars equal $0.5 \mathrm{~mm}$. 
about the interaction between host and parasite. We have demonstrated that Orobanche triggers the localized induction of the defense-related $h m g 2$ gene as an early event in host penetration process and throughout the parasitization process. This induction response is presumably analogous to pathogeninduced $h m g 2$ gene activation associated with the production of sesquiterpenoid phytoalexin defense compounds. Joel and Losner-Goshen (1994b) previously reported Orobanchemediated induction of a PR gene in O. aegyptiaca-parasitized transgenic tobacco expressing a $P R B-1 b$ promoter:GUS construct. The $P R B-1 b$ gene encodes a basic-type PR-1 protein whose transcription is regulated by ethylene (Meller et al.
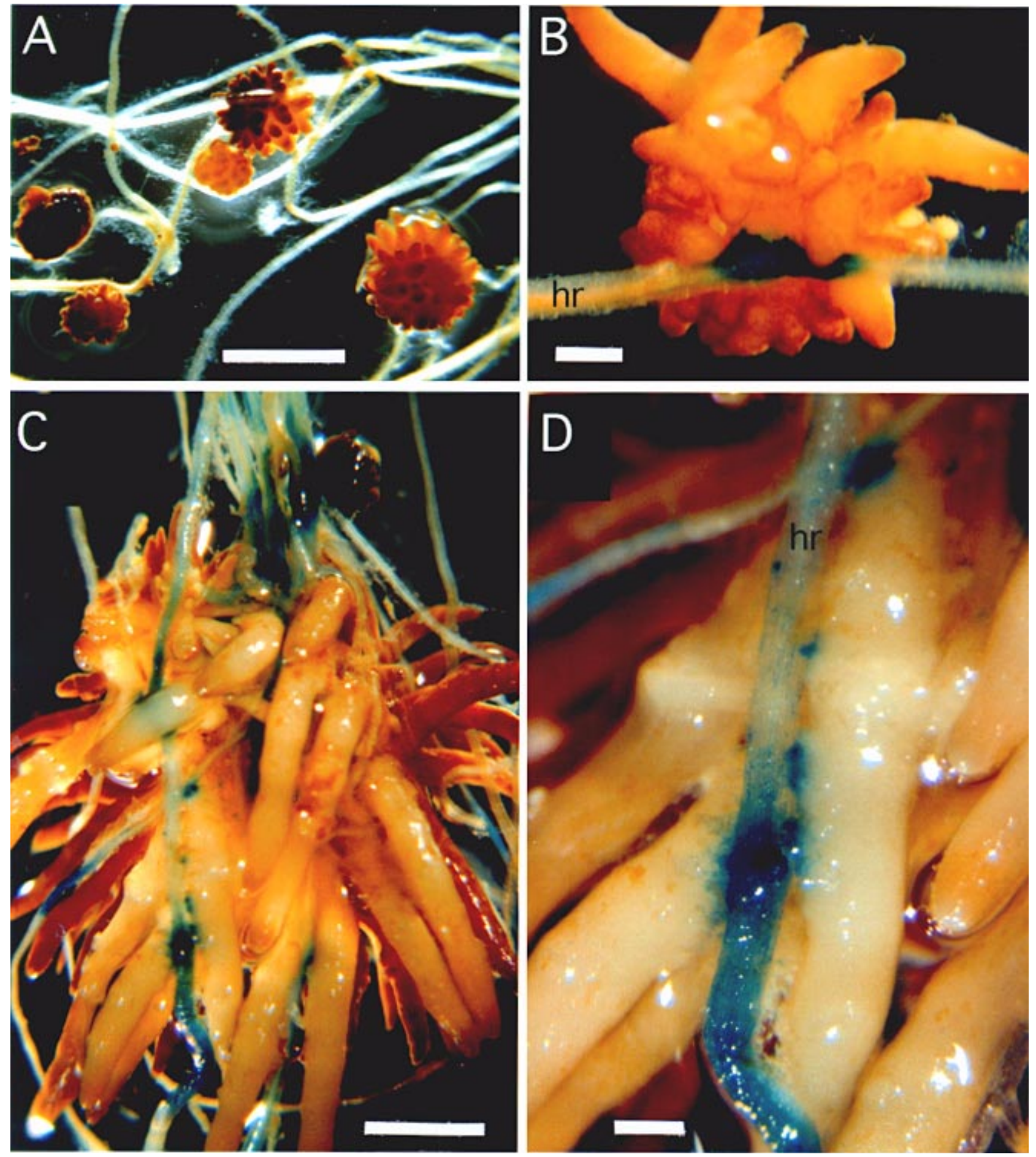

Fig. 2. Orobanche aegyptiaca tubercles growing on roots of tobacco expressing either 35S:GUS (A) or hmg2:GUS (B, C, D) gene constructs. In response to parasitism by $O$. aegyptiaca, GUS expression is evident in the host roots (hr) containing $h m g 2$ :GUS (B), but not those with $35 \mathrm{~S}$ : GUS (A). The secondary roots of a 4-week-old $O$. aegyptiaca tubercle also induce GUS expression in the host roots $(\mathbf{C}$, and at higher magnification in $\mathbf{D})$. Bars equal $0.5 \mathrm{~cm}$ in $\mathbf{A}$ and $\mathbf{C}$, and $1 \mathrm{~mm}$ in $\mathbf{B}$ and $\mathbf{D}$. 
1993). During pathogen (e.g., viral, bacterial, fungal) attack, $P R-1$ genes are rapidly induced to high levels at the site of ingress and subsequently induced throughout the plant as part of the systemic acquired resistance (SAR) response (reviewed in Ryals et al. 1996). Induction of the PR genes involves the salicylic acid (SA) signaling pathway (Hammond-Kosack and Jones 1996; Sano et al. 1996; Ward et al. 1991). In contrast, hmg 2 shows no systemic induction, is not induced by SA, and thus represents a distinct signal transduction pathway (Choi et al. 1992; Weissenborn et al. 1995). Although the temporal pattern of $P R-1$ expression in relation to Orobanche development was not described, induction of both of these independently regulated, defenserelated genes suggests that Orobanche induces a wide array of defense responses in the host.

The mechanism of early penetration remains poorly understood, although studies indicate that both mechanical pressure and enzymatic digestion of cell wall components are involved (Ben-Hod et al. 1993; Joel and Losner-Goshen 1994b; Shomer-Ilan 1993). Based on the timing of initial GUS activity (Fig. 1), hmg2 induction requires host root penetration by Orobanche. Figure 1D, E, and F represent interactions occurring within the first $24 \mathrm{~h}$ of contact, but illustrate distinct stages of development. Figure 1D shows a parasite seedling that had adhered to the host root, but either had not penetrated or was just starting to penetrate the root; no GUS activity was evident at this time. However, in Figure $1 \mathrm{E}$ and F, both the parasite haustorium connecting the $O$. aegyptiaca seedling to the host vascular tissue and GUS staining are visible. Tomato (and potato) $h m g 2$ is activated by wounding, but significantly greater transcript levels are seen after treatment with pathogens or elicitors (Cramer et al. 1993; Choi et al. 1992; Yang et al. 1991). Thus, Orobanche-mediated induction of $h m g 2$ may be caused by either mechanical disruption of the root epidermal and cortical cells, or by secretion of lytic enzymes (known to release endogenous elicitors from host cell walls) by the parasite. Analyses of $P R B-1 b$ :GUS transgenic plants during early penetration events may distinguish which component is triggering these initial defense responses since the $P R-1$ genes are not wound-inducible.

Wound- and elicitor-mediated induction of $h m g 2$ is generally transient; RNA analyses suggest that $h m g 2$ transcript levels peak between 9 and $24 \mathrm{~h}$ (depending on the insult) and are quite low by $48 \mathrm{~h}$ (Weissenborn et al. 1995; Yang et al. 1991). Clearly, hmg2 induction by Orobanche is not limited to a transient response to host injury. Rather, the GUS expression patterns indicate that $h m g 2$ transcription continues throughout the development of the parasite. Figure $1 \mathrm{G}, \mathrm{H}$, and I show growth of the $O$. aegyptiaca tubercle through the first 10 days after attachment, with increasing intensity of GUS staining during that time. Although GUS is considered a relatively stable protein, we have observed the appearance and disappearance of GUS activity within a 24-h period in unrelated analyses of tissue-specific promoter regulation (Zhou et al. 1997). Thus, our data suggest a sustained induction of host defenses, possibly reflecting new wounding as the haustorium enlarges. Indeed, Orobanche-host interactions often show a fissure in the cortex running lengthwise along the host root, with the parasite connected to the host tissue through the fissure. The continued GUS expression could be a result of the haustorium acting as a wedge that steadily expands the fissure. Little is known about the long-term development of the haustorium and whether invasive growth, including establishment of new vascular connections, continues during tubercle enlargement, but the GUS expression patterns observed are consistent with this possibility.

Apart from the continued GUS expression at the original site of Orobanche connection, hmg2:GUS-related staining was also evident where the secondary roots of $O$. aegyptiaca contacted roots of the host plant (Fig. 2C and D). Although such secondary attachments have been reported in Orobanche (Kuijt 1977) and have been the subject of detailed anatomical studies in $O$. crenata Forsk. (Dörr and Kollmann 1974, 1975), it has not been feasible to address questions concerning the physiological role of these attachments in comparison to primary attachments. Our results indicate that the host response, as indicated by $h m g 2$ expression, is similar for each type of parasitic attachment, and emphasize the localized nature of the $h m g 2$ regulation because each new haustorial contact point triggered a response independent of previous attachments.

These findings raise several questions about the host response to parasitization by Orobanche. The first of these is why host plants are susceptible to Orobanche parasitization when they are clearly able to detect the parasite and initiate a defense response. We tested the ability of $O$. aegyptiaca to parasitize transgenic tobacco plants that over-expressed $h m g 2$ and showed increased resistance to viral and bacterial pathogens, but these were equally susceptible to Orobanche as control plants (J. H. Westwood, X. Yu, and C. L. Cramer, unpublished results). It is possible that the phytoalexins of tobacco are geared toward microbial pathogens and are not effective against Orobanche, which is a fellow angiosperm.

This study has shown a rapid and sustained induction of the defense-response gene hmg2 during parasitization by Orobanche. The power of the experimental approach of using promoter:GUS fusions is that we are able to begin dissecting at the molecular level the interaction between two complex and phylogenetically relatively closely related organisms. Analogous strategies have been instrumental in enhancing our understanding of events in plant response to parasitic nematodes (Goddijn et al. 1993; Williamson and Hussey 1996). In addition to activating defense-related genes, $O$. aegyptiaca parasitization induces expression of genes involved in nutrient allocation. We have recently demonstrated that the plant protein-farnesyltransferase, which post-translationally modifies signaling proteins, functions not only in cell cycle control but also in nutrient partitioning (Qian et al. 1996; Zhou et al. 1997). Transgenic tobacco expressing farnesyltransferase promoter:GUS fusions also exhibit GUS activity in response to parasitization by Orobanche (J. H. Westwood, D. Zhou, C. L. Foy, and C. L. Cramer, unpublished data). This is consistent with Orobanche representing a strong sink on the host root (Aber et al. 1983; Press 1995). Application of promoter:reporter gene strategies with other genes of interest will greatly expand our understanding of host-parasite interactions at the level of genetic regulation. In addition, identification of promoter elements that are induced specifically in response to Orobanche penetration may be useful in engineering appropriate resistance mechanisms into crop plants, thereby providing the potential for reducing the economic losses resulting from Orobanche infestations. 


\section{MATERIALS AND METHODS}

\section{Plant material.}

Transgenic plants of tobacco (Nicotiana tabacum cultivars NC 95 [line 104] and Xanthi [line 002]) were previously generated by Agrobacterium-mediated transformation (Horsch et al. 1985) with a gene construct fusing $2.3 \mathrm{~kb}$ of the tomato hmg2 promoter with the GUS reporter gene (Cramer et al. 1993; Jefferson 1987; Yu 1995). A Xanthi line was also transformed with the CaMV 35S promoter (Koziel et al. 1984) fused with the GUS gene (line 209) and was used as a constitutively expressing control. For all three transgenic lines, the original transformant $\left(\mathrm{T}_{0}\right)$ contained a single transgene insert and the segregating $\mathrm{T}_{1}$ seeds were used for Orobanche inoculations. Seeds were surface sterilized and germinated on a medium of MS salts (Murashige and Skoog 1962) containing $50 \mathrm{mg}$ of kanamycin per liter to select for transformed plants. Kanamycin-resistant seedlings were transplanted to petri plates where their roots were placed beneath a glass fiber filter membrane that had been moistened with autoclaved, $0.5 \times$ Hoagland solution (Hoagland and Arnon 1950). Plates were sealed and placed at a $30^{\circ}$ angle, and plants allowed to grow at $25^{\circ} \mathrm{C}$ under fluorescent lighting $\left(100 \mu \mathrm{E} \cdot \mathrm{s}^{-1} \cdot \mathrm{m}^{-2}\right)$ until plantlets had developed a suitable root system for inoculation. The Orobanche spp. used were $O$. aegyptiaca and $O$. ramosa.

\section{Growth conditions for tobacco-Orobanche interaction.}

Studies of early parasitization events were conducted directly in the petri plates. The filter membrane was inverted so that tobacco roots were on the upper side, and surfacesterilized Orobanche seeds were placed along the tobacco roots. Orobanche seeds were sterilized by washing in $70 \%$ ethanol for $30 \mathrm{~s}$, followed by a $1 \%$ sodium hypochlorite solution for $20 \mathrm{~min}$, and then rinsed thoroughly. In one experiment pre-germinated seeds of $O$. aegyptiaca were placed with radicles contacting roots, and while these were able to adhere to the roots, no successful attachments were found. In all other experiments ungerminated seeds were spread around the host roots and the strigol analog, GR-24 (10 mg/liter), was added to synchronize Orobanche germination (Mangnus et al. 1992). Orobanche radicles emerged 3 to 4 days following addition of stimulant and plates were monitored to determine the time of first contact between parasite radicle and host root. At various times after this event, GUS activity was determined by staining plates in situ (see below) such that host roots and parasites were not disturbed at any time (Jefferson 1987).

Studies of later Orobanche development were conducted with hosts grown in polyethylene bags (modified from Parker and Dixon 1983). Roots of transgenic tobacco seedlings were placed in contact with a sheet of glass fiber membrane held in a polyethylene bag. Shoots were allowed to project from the top of the bag to receive light while the root systems were held in a darkened box. Moisture for the root system was maintained by keeping the glass fiber membrane in contact with a reservoir of $0.5 \times$ Hoagland solution in the bottom of the bag. Seeds of $O$. aegyptiaca that had been surface sterilized as described above were spread on the membrane around and below the tobacco roots. Germination was stimulated by allowing $5 \mathrm{ml}$ of GR-24 solution (1 mg/liter) to diffuse throughout the membrane while the bag was lying horizontally. Host plants were grown in light and temperature condi- tions identical to those described above. After the parasites had developed for 4 weeks, sections of roots containing Orobanche plants were removed and stained to detect GUS expression.

\section{GUS detection.}

For experiments in petri plates, excess Hoagland solution was removed and plates were flooded with a shallow layer of GUS staining solution containing $1 \mathrm{mM}$ 5-bromo-4-chloro-3indolyl- $\beta$-D glucuronide (Jefferson 1987). For experiments in bags, sections of host root extending several centimeters above and below Orobanche attachments were cut free and immersed in the GUS staining solution. In all cases the roots were vacuum infiltrated three times, each for $1 \mathrm{~min}$. Tissues were incubated at $37^{\circ} \mathrm{C}$ and evaluated after $24 \mathrm{~h}$.

\section{ACKNOWLEDGMENTS}

This project was supported by USAID grant no. HNE-0158-G-003060-00 to C. L. F. and USDA/NRICGP grant no. 97-35315-4206. Generation of transgenic plants expressing promoter:GUS fusions was part of a project supported by NIH R29-GM39549, NSF grant IBN-9514177, and USDA Hatch Project no. 1671293 to C. L. C. Orobanche seeds were generously provided by Y. Kleifeld, Newe Ya'ar Research Center, Israel. We thank B. Shirley and E. Grabau for their critical reviews of the manuscript.

\section{LITERATURE CITED}

Aber, M., Fer, A., and Sallé, G. 1983. Etude du transfert des substances organiques de l'hôte (Vicia faba) vers le parasite (Orobanche crenata Forsk.). Z. Pflanzenphysiol. 112:297-308.

Ben-Hod, G., Losner, D., Joel, D. M., and Mayer, M. 1993. Pectin methylesterase in calli and germinating seeds of Orobanche aegyptiaca. Phytochemistry 32:1399-1402.

Chappell, J. 1995. Biochemistry and molecular biology of the isoprenoid biosynthetic pathway in plants. Annu. Rev. Plant Physiol. Plant Mol. Biol. 46:521-548.

Choi, D., Ward, B. L., and Bostock, R. M. 1992. Differential induction and suppression of potato 3-hydroxy-3-methylglutaryl coenzyme A reductase genes in response to Phytophthora infestans and to its elicitor arachidonic acid. Plant Cell 4:1333-1344.

Cramer, C. L., Weissenborn, D., Cottingham, C. K., Denbow, C. J., Eisenback, J. D., Radin, D. N., and Yu, X. 1993. Regulation of defenserelated gene expression during plant-pathogen interactions. J. Nematol. 25:507-518.

Cubero, J. I. 1991. Breeding for resistance to Orobanche species: A review. Pages 257-277 in: Progress in Orobanche Research. K. Wegmann and L. J. Musselman, eds. Eberhard-Karls-Universität, Tübingen, Germany.

Dörr, I. 1996. New results on interspecific bridges between parasites and their hosts. Pages 195-201 in: Advances in Parasitic Plant Research. M. T. Moreno, J. I. Cubero, D. Berner, D. Joel, and L. J. Musselman, eds. Junta de Andalusia, Cordoba, Spain.

Dörr, I., and Kollmann, R. 1974. Structural features of parasitism of Orobanche I. Growth of the haustorial cells within the host tissue. Protoplasma 80:245-259.

Dörr, I., and Kollmann, R. 1975. Structural features of parasitism of Orobanche II. The differentiation of assimilate conducting elements within the haustorium. Protoplasma 83:185-199.

Foy, C. L., Jain, R., and Jacobsohn, R. 1989. Recent approaches for chemical control of broomrape (Orobanche spp.). Rev. Weed Sci. 4: 123-152.

Goddijn, O. J. M., Lindsey, K., Van der Lee, F. M., Klap, J. C., and Sijmons, P. C. 1993. Differential gene expression in nematode-induced feeding structures of transgenic plants harbouring promoter-gusA fusion constructs. Plant J. 4:863-873.

Gressel, J., Segel, L., and Ransom, J. K. 1996. Managing the delay of evolution of herbicide resistance in parasitic weeds. Int. J. Pest 
Manag. 42:113-129.

Hammond-Kosack, K. E., and Jones, J. D. G. 1996. Resistance genedependent plant defense responses. Plant Cell 8:1773-1791.

Hoagland, D. R., and Arnon, D. I. 1950. The water-culture method for growing plants without soil. Calif. Agric. Exp. Sta. Circ. 347:1-32.

Horsch, R. B., Fry, J. E., Hoffmann, N. L., Eichholtz, D., Rogers, S. G., and Fraley, R. T. 1985. A simple and general method for transferring genes into plants. Science 227:1229-1231.

Ismail, A. M. A., and M. Obeid. 1976. A study of assimilation and translocation in Cuscuta hyalina Heyne ex Roth., Orobanche ramosa L. and Striga hermonthica Benth. Weed Res. 16:87-92.

Jefferson, R. A. 1987. Assaying chimeric genes in plants: The GUS gene fusion system. Plant Mol. Biol. Rep. 5:387-405.

Joel, D. M., Kleifeld, Y., Losner-Goshen, D., Herzlinger, G., and Gressel, J. 1995. Transgenic crops against parasites. Nature 374:220-221.

Joel, D. M. and Losner-Goshen, D. 1994a. The attachment organ of the parasitic angiosperms Orobanche cumana and O. aegyptiaca and its development. Can. J. Bot. 72:564-574.

Joel, D. M. and Losner-Goshen, D. 1994b. Early host-parasite interaction: models and observations of host root penetration by the haustorium of Orobanche. Pages 237-247 in: Proc. Int. Worksh. on Orobanche and Related Striga Res., 3rd. A. H. Pieterse, J. A. C. Verkleij, and S. J. ter Borg, eds. Royal Tropical Institute, Amsterdam.

Koziel, M. G., Adams, T. L., Hazlet, M. A., Damm, D., Miller, J., Dahlbeck, D., Jayne, S., and Staskawicz, B. J. 1984. A cauliflower mosaic virus promoter directs expression of kanamycin resistance in morphogenic transformed plant cells. J. Mol. Appl. Genet. 2:549-562.

Kuijt, J. 1977. Haustoria of phanerogamic parasites. Annu. Rev. Phytopathol. 17:91-118.

Lamb, C. J., Lawton, M. A., Dron, M., and Dixon, R. A. 1989. Signals and transduction mechanisms for activation of plant defenses against microbial attack. Cell 56:215-224.

Lane, J., Bailey, J. A., Butler, R. C., and P. J. Terry. 1993. Resistance of cowpea [Vigna unguiculata (L.) Walp to Striga gesneroides (Willd.) Vatke, a parasitic angiosperm. New Phytol. 125:405-412.

Mangnus, E. M., Stommen, P. L. A., and Zwanenburg, B. 1992. A standardized bioassay for evaluation of potential germination stimulants for seeds of parasitic weeds. J. Plant Growth Regul. 11:91-98.

Meller, Y., Sessa, G., Eyal, Y., and Fluhr, R. 1993. DNA-protein interactions on a cis-DNA element essential for ethylene regulation. Plant Mol. Biol. 23:453-463

Murashige, T., and Skoog, F. 1962. A revised medium for rapid growth and bio assays with tobacco tissue cultures. Physiol. Plant. 15:473497.

Park, H., Denbow, C. J., and Cramer, C. L. 1992. Structure and nucleotide sequence of tomato HMG2 encoding 3-hydroxy-3-methylglutaryl coenzyme A reductase. Plant Mol. Biol. 20:327-331.

Parker, C., and Dixon, N. 1983. The use of polyethylene bags in culture study of Striga spp. and other organisms on crop roots. Ann. Appl. Biol. 103:485-488

Parker, C., and Riches, C. R. 1993. Parasitic Weeds of the World: Biology and Control. CAB Int., Wallingford, UK.

Press, M. C. 1995. Carbon and nitrogen relations. Pages 103-124 in: Parasitic Plants. M. C. Press and J. D. Graves, eds. Chapman and Hall, London.

Press, M. C., Graves, J. D., and Stewart, G. R. 1990. Physiology of the interaction of angiosperm parasites and their higher plant hosts. Plant
Cell Environ. 13:91-104.

Qian, D., Zhou D., Ju, R., Cramer, C. L., and Yang, Z. 1996. Protein farnesyltransferase: Molecular characterization and involvement in plant cell cycle control. Plant Cell 8:2381-2394.

Ryals, J. A., Neuenschwander, U. H., Willits, M. G., Molina, A., Steiner, H.-Y., and Hunt, M. D. 1996. Systemic acquired resistance. Plant Cell 8:1809-1819.

Sano, H., Seo, S., Koizumi, N., Niki, T., Iwanura, H., and Ohashi Y. 1996. Regulation by cytokinins of endogenous levels of jasmonic and salicylic acids in mechanically wounded tobacco plants. Plant Cell Physiol. 37:762-769.

Sauerborn, J. 1991. The economic importance of the phytoparasites Orobanche and Striga. Pages 137-143 in: Proc. Int. Symp. on Parasitic Weeds, 5th. J. K. Ransom, L. J. Musselman, A. D. Worsham, and C. Parker, eds. CIMMYT, Nairobi, Kenya.

Shomer-Ilan, A. 1993. Germinating seeds of the root parasite Orobanche aegyptiaca Pers. excrete enzymes with carbohydrase activity. Symbiosis 15:61-70.

Stewart, G. R., and Press, M. C. 1990. The physiology and biochemistry of parasitic angiosperms. Annu. Rev. Plant Physiol. Plant Mol. Biol. 41:127-151.

Visser, J., and Dörr, I. 1987. The haustorium. Pages 91-106 in: Parasitic Weeds in Agriculture, Vol. I. Striga. L. J. Musselman, ed. CRC Press, Boca Raton, FL.

Vogler, R. K., Ejeta, G., and Butler, L. G. 1996. Inheritance of low production of Striga germination stimulant in sorghum. Crop Sci. 36: 1185-1191.

Ward, E. R., Uknes, S. J., Williams, S. C., Dincher, S. S., Wiederhold, D. L., Alexander, D. C., Ahl-Goy, P., Metraux, J.-P., and Ryals, J. A. 1991. Coordinate gene activity in response to agents that induce systemic acquired resistance. Plant Cell 3:1085-1094.

Wegmann, K., von Elert, E., Harloff, H.-J., and Stadler, M. 1991. Tolerance and resistance to Orobanche. Pages 318-321 in: Progress in Orobanche Research. K. Wegmann and L. J. Musselman, eds. Eberhard-Karls-Universität, Tübingen, Germany.

Weissenborn, D. L., Denbow, C. J., Laine, M., Lång, S. S., Yang, Z., Yu, X., and Cramer, C. L. 1995. HMG-CoA reductase and terpenoid phytoalexins: molecular specialization within a complex pathway. Physiol. Plant. 93:393-400.

Westwood, J. H., Yu, X., Foy, C. L., and Cramer C. L. 1996. Parasitization by Orobanche induces expression of a defense-related gene in tobacco. Pages 543-550 in: Advances in Parasitic Plant Research. M. T. Moreno, J. I. Cubero, D. Berner, D. Joel, and L. J. Musselman, eds. Junta de Andalucia, Cordoba, Spain.

Williamson, V. M., and Hussey, R. S. 1996. Nematode pathogenesis and resistance in plants. Plant Cell 8:1735-1745.

Yang, Z., Park, H., Cramer, C. L, and Lacy, G. H. 1991. Differential induction of potato 3-hydroxy-3-methylglutaryl coenzyme A reductase isogenes by wounding and bacterial challenge. Plant Cell 3:397-405.

Yu, X. 1995. Functional analysis of tomato 3-hydroxy-3-methylglutaryl coenzyme A reductase (HMGR) gene in transgenic plants engineered for altered HMGR expression. Ph.D. diss. Virginia Polytechnic Institute and State University, Blackburg.

Zhou, D., Qian, D., Cramer, C. L., and Yang, Z. 1997. Developmental and environmental regulation of tissue- and cell-specific expression of a pea protein farnesyltransferase gene in transgenic plants. Plant J. 12: 921-930. 